\title{
THE USE OF ZINC OXIDE IN DETERMINATIONS OF COBALT AND MANGANESE
}

\author{
By James I. Hoffman
}

ABSTRACT

This paper presents data on the behavior of the constituents of steel in precipitations by zinc oxide and gives directions for the determination of cobalt. The use of precipitations with zinc oxide in determinations of manganese and nickel and the purity of the zinc oxide reagent are also discussed.

\section{CONTENTS}

I. Introduction 883

II. The zinc oxide reagent

III. Determination of cobalt in steel

1. Routine determination (single precipitation by zinc oxide) - - 885

2. Umpire determination (double precipitation by zinc oxide) -_- 887

IV. Determination of manganese 888

$\mathrm{V}$. Behavior of other constituents of steel in the precipitation by zinc oxide

1. Iron.

2. Nickel.

889

Tungsten

4. Vanadium .

890

5. Chromium

890

6. Copper and molybdenum

7. Uranium ..........

8. Zirconium and titanium

9. Silicon....... 891

10. Aluminum.

11. Phosphorus, arsenic, antimony, tin (lead) 891

VI. Conclusions

891

VII. Acknowledgment.

\section{INTRODUCTION}

According to Britton ${ }^{1}$ the hydroxides of zinc, nickel, cobalt, and manganese (bivalent) are precipitated at $\mathrm{pH}$ values of $5.2,6.7,6.8$, and 8.5 to 8.8 , respectively, whereas the hydroxides of iron, trivalent chromium, and some other constituents of steel are precipitated at lower $\mathrm{pH}$ values. The addition of an excess of zinc oxide to a slightly acid solution of a steel, therefore, offers an attractive means of separating cobalt, manganese, and nickel, which remain in solution, from the other constituents, which are precipitated.

It may be said in anticipation (1) that conditions can be established whereby iron, chromium, vanadium, tungsten, uranium, zirconium, titanium, aluminum, phosphorus, arsenic, and tin are completely precipitated; and (2) that precipitation of copper, molybdenum, and silicon is not quite complete.

Separations made by precipitating with zinc oxide are especially useful if cobalt is to be determined afterwards by precipitation by

\footnotetext{
1 H. T. S. Britton, Hydrogen Ions, p. 278, 1929 ed., D. Van Nostrand Co.
} 
a-nitroso- $\beta$-naphthol, and find occasional application in determinations of manganese in steel containing much chromium or vanadium. Most textbooks recommend precipitation by zinc oxide for the separation of manganese or cobalt from the other constituents of steel if subsequent operations require the absence of these constituents. Some recommend that the precipitation be made in hot solutions; others prescribe cold solutions. ${ }^{2}$ None of these gives any data with respect to the completeness of the separation. As works and commercial laboratories at present are using the method for the determination of cobalt and manganese, it seems desirable that such data should be presented. There are many variations of minor details of the method, but the procedure described in Section III for the determination of cobalt in high-speed steels by making a single precipitation is typical of these procedures. In all instances in which precipitations by zinc oxide were made in hot solutions (see Tables 1 , 2 , and 3 ) the solutions were cooled to room temperature before filtering.

\section{THE ZINC OXIDE REAGENT}

The suspension of zinc oxide used in this work was prepared by thoroughly shaking $50 \mathrm{~g}$ of the finely powdered reagent with $300 \mathrm{ml}$ of water. Ten $\mathrm{ml}$ of this suspension remained colorless upon addition of two drops of a 1 per cent solution of phenolphthalein, thus showing the absence of sodium carbonate. Lord and Demorest ${ }^{3}$ state that the zinc oxide should not contain any alkali, because this would precipitate manganese (also nickel and cobalt). Owing to the slight excess of reagent added, a small contamination by sodium carbonate does not affect the results seriously, as is shown by the following tests.

Precipitates obtained by double precipitations with zinc oxide as described in the determination of cobalt (Section III) were dissolved and analyzed for cobalt, manganese, and nickel. The tests were made on three steels containing 5 per cent of cobalt, 0.94 per cent of manganese, and 8.44 per cent of nickel, respectively. Three different reagents were used, and the suspensions were prepared as described. The first was the ordinary reagent, which showed no alkaline reaction with phenolphthalein; the second was the same reagent, to which 0.1 per cent of sodium carbonate was added and intimately ground in a mortar; the third was a similarly prepared reagent containing 0.5 per cent of sodium carbonate. The precipitates obtained by the use of the ordinary reagent showed 0.01 per cent of cobalt, no manganese, and 0.09 per cent of nickel; those with the reagent containing 0.1 per cent of sodium carbonate showed 0.02 per cent of cobalt, no manganese, and 0.10 per cent of nickel; and those with the reagent containing 0.5 per cent of sodium carbonate showed 0.02 per cent of cobalt, no manganese, and 0.10 per cent of nickel. It is obvious, however, that a large excess of a reagent containing sodium carbonate would precipitate cobalt, manganese, and nickel, and that a reagent that does not give an alkaline reaction with phenolphthalein should be used.

${ }^{2}$ N. W. Lord and D. J. Demorest, Metallurgical Analysis, p. 82, 1924 ed., McGraw-Hill Book Co., recommend precipitation in a hot solution. F. T. Sisco, Analysis of Steel, p. 229, 1923 ed., McGraw-Hill Book Co., recommends precipitation in a cold solution. W. A. Naish and J. E. Clennell, Select Methods of Mietallurgical Aanalysis, p. 365, 1930 ed., J. Wiley \& Sons, recommend that an excess of ZnO be added and the solution then boiled for 10 minutes in the determination of cobalt in steel.

$\therefore$ N. W. Lord and D. J. Demorest, Metallurgical Analysis, p. 82, 1924 ed., McGraw-Hill Book Co. 


\section{DETERMINATION OF COBALT IN STEEL}

The following procedures were used in the determination of cobalt in the experimental work, and are recommended for the determination of cobalt in steels. In these methods iron and most of the elements that interfere are separated from cobalt by single or double precipitations with zinc oxide followed by filtration. The cobalt is then precipitated in the filtrate by a-nitroso- $\beta$-naphthol and ignited to the oxide or the metal. Besides iron, the elements that interfere in a precipitation by $a$-nitroso- $\beta$-naphthol and which may be present in steel are copper, chromium, vanadium, tungsten, molybdenum, tin, and antimony.

\section{ROUTINE DETERMINATION OF COBALT IN STEEL (SINGLE PRE- CIPITATION BY ZINC OXIDE)}

Transfer $2.00 \mathrm{~g}$ of sample to a $600 \mathrm{ml}$ beaker, add $50 \mathrm{ml}$ of dilute hydrochloric acid $(1: 1)$, heat, and when decomposition is complete, add $10 \mathrm{ml}$ of dilute nitric acid $(1: 1)$ to oxidize the iron and tungsten. Evaporate until salts begin to separate (5 to $10 \mathrm{ml}$ ), and then add $100 \mathrm{ml}$ of hot water. Digest on the steam bath for a few minutes, and transfer the contents of the beaker to a $500 \mathrm{ml}$ volumetric flask. Dilute to about $300 \mathrm{ml}$, and add a freshly prepared suspension of zinc oxide in portions of about $5 \mathrm{ml}$ until the iron is precipitated and a slight excess of zinc oxide is present. Shake thoroughly after each addition of the precipitant and avoid a large excess. When sufficient zinc oxide has been added, further addition of the reagent causes the brown precipitate to appear lighter in color upon thorough shaking. A sufficien't excess of zinc oxide is also indicated by a slightly white and milky supernatant liquid.

Dilute to the mark, mix thoroughly, and transfer the contents of the flask to the original dry beaker. Allow the precipitate to settle, and filter through a dry paper. Discard the first 10 to $15 \mathrm{ml}$ of filtrate, and then catch exactly $250 \mathrm{ml}$ in a dry volumetric flask. Transfer the solution to a $600 \mathrm{ml}$ beaker, add $10 \mathrm{ml}$ of hydrochloric acid, and dilute to about $400 \mathrm{ml}$.

Heat the solution to boiling, and add $6 \mathrm{ml}$ of $\alpha$-nitroso- $\beta$-naphthol solution ${ }^{4}$ for every $0.01 \mathrm{~g}$ of cobalt present. Allow the solution to cool for one-half to two hours, and filter through a No. 40 Whatman or similar paper. The filtration proceeds best if the precipitate is thoroughly stirred as the solution is poured on the paper. Transfer all of the precipitate to the filter and wash thoroughly with hot dilute hydrochloric acid $(1: 2)$ and then with hot water.

Transfer the paper and precipitate to a weighed porcelain crucible, and ignite slowly at first (preferably in a muffie) and finally at $750^{\circ}-900^{\circ} \mathrm{C}$. Heating above $900^{\circ} \mathrm{C}$. has a tendency to convert $\mathrm{Co}_{3} \mathrm{O}_{4}$ to $\mathrm{CoO} .^{5}$ Cool, and weigh as $\mathrm{Co}_{3} \mathrm{O}_{4}$, which contains 73.4 per cent of cobalt.

A blank should be taken through all steps of the determination. A $2 \mathrm{~g}$ sample of Bureau of Standards ingot iron No. 55 or chrometungsten-vanadium steel No. 50a is satisfactory for this purpose.

\footnotetext{
4 Prepare by dissolving $1 \mathrm{~g}$ of the dry reagent in $15 \mathrm{ml}$ of glacial acetic acid and filtering.
6 Ignition at $1,000^{\circ} \mathrm{C}$., or higher, converts $\mathrm{Co}_{3} \mathrm{O}_{4}$ almost quantitatively to $\mathrm{CoO}$, and application of the factor for cobalt in $\mathrm{Co}_{3} \mathrm{O}_{4}(0.734)$ to the oxide, $\mathrm{CoO}$, would yield a result of 4.67 in a steel that contains 5.00 per cent of cobalt. This error can be avoided by reducing the oxide in hydrogen and weighing the metal
} 
Any similar material known to be free from cobalt should also be satisfactory. It is especially important that the same quantity of $a$-nitroso- $\beta$-naphthol be used in the blank run as in the determination. A litte macerated paper added to the blank after the a-nitroso$\beta$-naphthol reagent facilitates filtration and washing.

TABLE 1.-Results for cobalt obtained by precipitation by $\alpha$-nitroso- $\beta$-naphthol after a single precipitation by zinc oxide

\begin{tabular}{|c|c|c|c|c|c|c|c|}
\hline \multirow[b]{2}{*}{ No. } & \multirow[b]{2}{*}{ Material analyzed } & \multirow[b]{2}{*}{$\begin{array}{l}\text { Cobalt } 1 \\
\text { added }\end{array}$} & \multicolumn{2}{|c|}{$\begin{array}{l}\text { Cobalt found } \\
\text { weighed as- }\end{array}$} & \multirow{2}{*}{$\begin{array}{c}\text { Error } \\
\text { (based } \\
\text { on dif- } \\
\text { ference } \\
\text { be- } \\
\text { tween } \\
\text { amount } \\
\text { added } \\
\text { and } \\
\text { amount } \\
\text { found } \\
\text { by ig- } \\
\text { nition } \\
\text { in } \mathrm{H}_{2} \text { ) }\end{array}$} & \multirow{2}{*}{$\begin{array}{l}\text { Other elements } \\
\text { added }\end{array}$} & \multirow[b]{2}{*}{$\begin{array}{l}\text { Temperature } \\
\text { of } \mathrm{ZnO} \text { precipits- } \\
\text { tion }\end{array}$} \\
\hline & & & $\begin{array}{c}\text { Co } \\
\text { metal } \\
\text { after re- } \\
\text { duction } \\
\text { in } \mathrm{H}_{2}\end{array}$ & $\begin{array}{l}\mathrm{Co}_{3} \mathrm{O}_{4} \\
\text { ignited } \\
\text { at } 750^{\circ}- \\
850^{\circ} \mathrm{C} \text {. }\end{array}$ & & & \\
\hline $\begin{array}{l}1 \\
2 \\
3\end{array}$ & $\begin{array}{l}2 \mathrm{~g} \mathrm{~B} . \mathrm{S} \text {. ingot iron Nu. } 55 \ldots \\
2 \mathrm{~g} \text { B. S. Cr-W-V steel No. }\end{array}$ & \begin{tabular}{|c|} 
Per cent \\
3.65 \\
3.65 \\
3.65
\end{tabular} & \begin{tabular}{|c|} 
Per cent \\
3.56 \\
3.52 \\
3.50
\end{tabular} & $\begin{array}{c}\text { Per cent } \\
3.57 \\
3.50 \\
3.48\end{array}$ & $\begin{array}{c}\text { Per cent } \\
-0.09 \\
-.13 \\
-.15\end{array}$ & $\begin{array}{c}\text { Per cent } \\
\text { Non } \theta_{-} \\
\end{array}$ & $\begin{array}{l}20^{\circ} \text { to } 30^{\circ} \mathrm{C} . \\
\text { Do. } \\
\text { Do. }\end{array}$ \\
\hline $\begin{array}{l}4 \\
5 \\
6 \\
7 \\
8\end{array}$ & 1 g $\mathrm{B} . \mathrm{S} . \mathrm{Cr}-\mathrm{W}-\mathrm{V}$ steel No. & $\begin{array}{l}3.65 \\
4.83 \\
4.83 \\
2.42 \\
2.42\end{array}$ & $\begin{array}{r}3.50 \\
4.60 \\
4.60 \\
2.35 \\
2.36\end{array}$ & $\begin{array}{l}3.48 \\
4.57 \\
4.59 \\
2.35 \\
2.34\end{array}$ & $\begin{array}{l}-.15 \\
-.23 \\
-.23 \\
-.07 \\
-.06\end{array}$ & 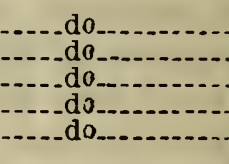 & $\begin{array}{l}\text { Do. } \\
\text { Do. } \\
\text { Do. } \\
\text { Do. } \\
\text { Do. }\end{array}$ \\
\hline 9 & $\begin{array}{l}2 \mathrm{~g} \mathrm{~B} . \mathrm{S} . \mathrm{Cr}-\mathrm{W}-\mathrm{V} \text { steel No. } \\
\text { 50a. }\end{array}$ & 4.83 & 4.59 & 4.56 & -.24 & -.... do............ & $100^{\circ}$ C.-cooled \\
\hline $\begin{array}{l}10 \\
11 \\
12 \\
13 \\
14\end{array}$ & 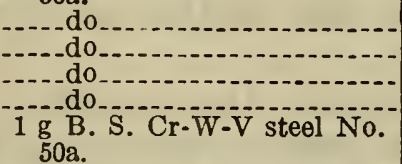 & $\begin{array}{l}4.83 \\
4.83 \\
4.83 \\
4.83 \\
9.66\end{array}$ & $\begin{array}{r}4.52 \\
34.60 \\
54.70 \\
54.64 \\
9.35\end{array}$ & $\begin{array}{l}4.51 \\
9.32\end{array}$ & $\begin{array}{l}-.31 \\
=.23 \\
=.13 \\
=.19 \\
-.31\end{array}$ & $\begin{array}{l}0.5 \mathrm{Cu}+0.5 \mathrm{Mo} \\
0.5 \mathrm{Mo} \\
0.5 \mathrm{Cu} \\
\text { None }\end{array}$ & $\begin{array}{l}\text { before filtering. } \\
20^{\circ} \text { to } 30^{\circ} \mathrm{C} \text {. } \\
\text { Do. } \\
\text { Do. } \\
\text { Do. }\end{array}$ \\
\hline 15 & - do & 9.66 & 9.34 & 9.32 & -.32 & ..... do .. & Do. \\
\hline
\end{tabular}

1 The cobalt was added (before the sample was dissolved) in the form of a solution of cobalt sulphate which was standardized (1) by deposition of the metal by electrolysis, making proper corrections for nicke] and sulphur; and (2) by precipitation with a-nitroso- $\beta$-naphthol, ignition to oxide, and weighing as metal after reducing the oxide in hydrogen.

2 This steel has the following percentage composition: $\mathrm{C}, 0.66 ; \mathrm{Mn}, 0.287 ; \mathrm{P}, 0.020 ; \mathrm{S}, 0.007 ; \mathrm{Si}, 0.48 ; \mathrm{W}$, 18.25; Cr, 3.52; V, 0.97; Cu, 0.047; $\mathrm{Ni}, 0.045 ; \mathrm{Co}$, none found.

3 After removing the aliquot portion of the filtrate obtained in the precipitation by zinc oxide as described in the method, the filtration was continued, the crecipitate was washed with water, and the filtrate and washings were reserved. The precipitate containing the iron, chromium, etc., was dissolved in $\mathrm{HCl}$, and a second precipitetion was made as described in the method that follows (Section III, 2). The filtrate and washings obtained in the second precipitation were combined with the reserved solution, and the cobalt was then determined. The total amount of cobalt found was exactly that originally added. This indicates that the low result obtained in the first portion was caused by retention of cobalt in the first precipitate.

1 The ignited residue in this determination contained $1.1 \mathrm{mg}$ of $\mathrm{CuO}+\mathrm{MoO}_{8}$. If no correction for this had been made, the result would have been 4.61 per cent.

3 The ignited residue in these determinations contained from 0.8 to $1.2 \mathrm{mg}$ of oxides of copper or molybdenum and the results would have been from 0.06 to 0.10 per cent higher if correction for these had not been made.

The data in Table 1 show that if only one precipitation by zinc oxide is made, results for cobalt in the percentages usually present in high-speed steels are likely to be from 0.1 to 0.3 per cent low as a result of retention of cobalt in the bulky precipitate. The temperature at which the precipitation is made has little or no effect on the results. If the temperature of ignition of the cobalt oxide exceeds $900^{\circ} \mathrm{C}$., it is not unusual for results by this method to be as much as 0.5 per cent low in the case of steels containing approximately 5 per 
cent of cobalt. The procedure (Section III, 2), involving two precipitations by zinc oxide, gives results which are more nearly correct, and it does not require much more of the analyst's time.

\section{UMPIRE DETERMINATION OF COBALT IN STEEL (DOUBLE PRE- CIPITATION BY ZINC OXIDE)}

Transfer $1.00 \mathrm{~g}$ of sample to a $400 \mathrm{ml}$ beaker, add $25 \mathrm{ml}$ of dilute hydrochloric acid $(1: 1)$, heat, and when decomposition is complete, add $5 \mathrm{ml}$ of dilute nitric acid (1:1), to oxidize the iron and tungsten. Evaporate until salts begin to separate (about $5 \mathrm{ml}$ ). Add $100 \mathrm{ml}$ of hot water, and digest on the steam bath for about five minutes. Dilute the solution to about $200 \mathrm{ml}$, and precipitate with zinc oxide as in 1.

Allow the precipitate to settle for a few minutes, and filter the solution through a $12.5 \mathrm{~cm}$ filter paper. ${ }^{6}$ Wash the beaker and the precipitate on the filter three times with cold water. Reserve the filtrate and washings. When the filter has drained, transfer the paper and precipitate to the beaker in which the precipitation was made, add $12 \mathrm{ml}$ of hydrochloric acid, and stir the paper to a pulp. The iron should now be in solution; if it is not, add more hydrochloric acid, avoiding a large excess. Dilute the solution to $200 \mathrm{ml}$, and repeat the precipitation with zinc oxide. Filter on a $15 \mathrm{~cm}$ paper, and wash four or five times with cold water.

Combine the two filtrates and washings, add $10 \mathrm{ml}$ of hydrochloric acid, and adjust the volume to about $400 \mathrm{ml}$. Heat the solution to boiling, add $6 \mathrm{ml}$ of $a$-nitroso- $\beta$-naphthol solution for every $0.01 \mathrm{~g}$ of cobalt present, and proceed as directed in the method previously described, paying particular attention to blank runs and to the temperature of ignition. Weighing as metal after reducing the oxide in hydrogen is to be preferred, especially if a muffle furnace with good temperature control is not available. If more than 0.2 per cent of copper or molybdenum is present, these should be determined in the ignited residue and the proper correction made. The results obtained by this method are shown in Table 2.

- S \& S No. 589 blue or white band and Whatman No. 40 or 42 papers are satisfactory. If the looser papers are used, a little finely divided $\mathrm{ZnO}$ may pass through the paper at first. This is unobjectionable, because zinc is not precipitated by $\alpha$-nitroso- $\beta$-naphthol. 
TABLE 2.-Results for cobalt obtained by precipitation by $\alpha$-nitroso- $\beta$-naphthol after a double precipitation by zinc oxide

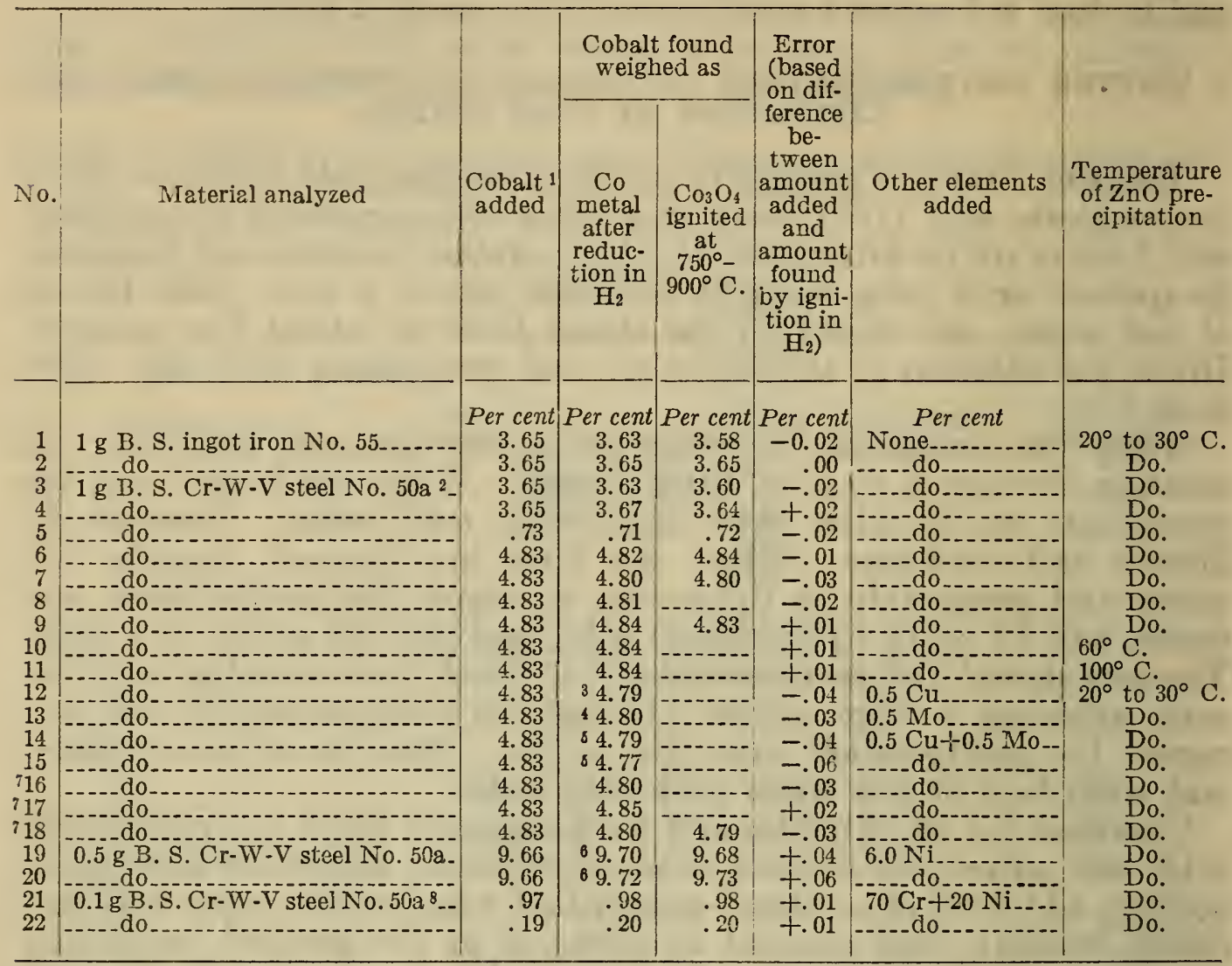

1 See footnote 1 under Table 1.

2 See footnote 2 under Table 1 .

8 Metal contained $0.2 \mathrm{mg}$ of copper. Uncorrected result was 4.81 per cent.

4 Metal contained $0.9 \mathrm{mg}$ of molybdenum. Uncorrected result was 4.89 per cent.

8 Results corrected for copper and molybdenum.

$\theta$ These results are uncorrected for nickel. They contained 0.02 per cent each.

7 After the samples were decomposed and the tungsten oxidized, the copper and molybdenum were precipitated by hydrogen sulphide without first removing the tungstic acid. The tungstic acid and sulphides of copper and molybdenum were then removed by filtration. Ten ml of nitric acid was added to the filtrate, which was evaporated to a volume of about $5 \mathrm{ml}$. The solution was then diluted and the precipitations by zinc oxide made as usual.

8 This mixture was analyzed to test the applicability of the method to the determination of cobalt in nickel-chromium resistance alloys.

If double precipitations by zinc oxide are made, the concentration of zinc chloride in the combined filtrates is materially increased, and the possibility of contamination of the precipitated cobalt by zinc must be considered. Two of the metallic residues (Nos. 6 and 10 in Table 2) were djssolved in hydrochloric acid and the cobalt reprecipitated by $a$-nitroso- $\beta$-naphthol. By igniting these precipitates, reducing in hydrogen, and weighing as cobalt metal, 4.81 and 4.82 per cent of cobalt were obtained, as compared with 4.82 and 4.84 per cent in the first precipitation. This shows that contomination by zinc is very slight and can usually be ignored.

\section{DETERMINATION OF MANGANESE}

Table 3 shows the results obtained for manganese by precipitating with zinc oxide as described under cobalt and then determining manganese in the filtrates by the bismuthate method. Because chlorides interfere in this determination, the samples were dissolved in $25 \mathrm{ml}$ of dilute sulphuric acid $(1: 5)$ and oxidized with nitric acid. 
TABLE 3.-Results for manganese obtained by the bismuthate method after single and double precipitations by zinc oxide

\begin{tabular}{|c|c|c|c|c|c|c|c|c|c|}
\hline No. & $\begin{array}{l}\text { Material } \\
\text { analyzed }\end{array}$ & $\begin{array}{c}\text { Man- } \\
\text { ganese } \\
\text { present }\end{array}$ & $\begin{array}{l}\text { Man- } \\
\text { ganese } \\
\text { found } \\
\text { after } \\
\text { single } \\
\text { precipi- } \\
\text { tation } \\
\text { with } \\
\text { ZnO }\end{array}$ & Error & $\begin{array}{l}\text { Man- } \\
\text { ganese } \\
\text { found } \\
\text { after } \\
\text { double } \\
\text { precipi- } \\
\text { tation } \\
\text { with } \\
\text { ZnO }\end{array}$ & Error & $\begin{array}{l}\text { Other } \\
\text { ele- } \\
\text { ments } \\
\text { adided }\end{array}$ & $\begin{array}{l}\text { Temperature } \\
\text { of ZnO pre- } \\
\text { cipitation }\end{array}$ & Remarks \\
\hline 1 & 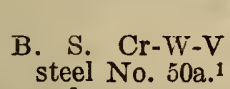 & $\begin{array}{c}\text { Per cent } \\
0.287\end{array}$ & $\begin{array}{c}\text { Per cent } \\
0.278\end{array}$ & $\begin{array}{l}\text { Per cen } \\
-0.009\end{array}$ & $\begin{array}{c}\text { Per cent } \\
0.285\end{array}$ & $\begin{array}{l}\text { Per cent } \\
-0.002\end{array}$ & Per cent & $90^{\circ}$ to $100^{\circ} \mathrm{C}$ - & \\
\hline 2 & do & .287 & .274 & -.013 & .283 & -.004 & & $20^{\circ}$ to $25^{\circ} \mathrm{C}$ & (Determined \\
\hline 3 & $\begin{array}{l}\text { B. S. ingot iron } \\
\text { No. } 55 \text {. }\end{array}$ & .019 & .021 & +.002 & .023 & +.004 & & $90^{\circ}$ to $100^{\circ} \mathrm{C}-$ & $\begin{array}{l}\text { manganese } \\
\text { colorimetri }\end{array}$ \\
\hline 4 & B.S. Cr-Ni (18-8) & .019 & .020 & +.001 & .024 & +.005 & & $20^{\circ}$ to $25^{\circ} \mathrm{C}$. & $\begin{array}{l}\text { cally by the } \\
\text { period od te } \\
\text { method. }\end{array}$ \\
\hline 5 & $\begin{array}{l}\text { B.S.Cr-Ni (18-8) } \\
\text { steel No.101.2 }\end{array}$ & .555 & .544 & -.011 & .560 & +.005 & & $90^{\circ}$ to $100^{\circ} \mathrm{C}$ - & \\
\hline 7 & $\begin{array}{l}\text { B. S. Cr-Mo steel } \\
\text { No. } 72 .^{3}\end{array}$ & .651 & .650 & -.001 & .655 & +.004 & $0.5 \mathrm{Cu}$ & $90^{\circ}$ to $100^{\circ} \mathrm{C}-$ & \\
\hline $\begin{array}{l}8 \\
9\end{array}$ & B. S. ferrovana- & $\begin{array}{l}.651 \\
3.57\end{array}$ & $\begin{array}{l}.650 \\
3.55\end{array}$ & $\begin{array}{l}-.001 \\
-.02\end{array}$ & .653 & +.002 & $0.5 \mathrm{Cu}_{-}$ & $\begin{array}{l}20^{\circ} \text { to } 25^{\circ} \mathrm{C}_{--} \\
90^{\circ} \text { to } 100^{\circ} \mathrm{C}_{-}\end{array}$ & \\
\hline 10 & do & 3.57 & 3. 57 & .00 & 3.60 & +.003 & & $20^{\circ}$ to $25^{\circ} \mathrm{C}_{-}-$ & t \\
\hline
\end{tabular}

1 See footnote 2 under Table 1.

2 This steel has the following percentage composition: C, 0.06; Min, 0.555; P, 0.014; S, 0.011; Si, 0.766; Cu, $0.054 ; \mathrm{Ni}, 8.44 ; \mathrm{Cr}, 17.53 ; \mathrm{V}, 0.045 ; \mathrm{Mo}, 0.005$.

3 This steel has the following percentage composition: C, 0.294; Mn, 0.651; P, 0.016; S, 0.021; Si, 0.137 ; $\mathrm{Cu}, 0.064 ; \mathrm{Ni}, 0.288 ; \mathrm{Cr}, 0.911$.

4 This sample bas the following percentage composition: V, 31.15, C, 1.15; Fe, 52.8; Mn, 3.57; P, 0.243; Si, 7.78; Cu, 0.29; Ni, 1.33; Cr, C.52; Mo, 0.72; Ti, 0.23 .

\section{BEHAVIOR OF OTHER CONSTITUENTS OF STEEL IN THE PRECIPITATION BY ZINC OXIDE}

\section{IRON}

Ferric iron is completely precipitated. Precipitation of ferrous iron is incomplete.

\section{NICKEL}

Separation of iron is not necessary in determinations of nickel in steel, but a few tests were made to ascertain the behavior of nickel. By making single precipitations with zine oxide, filtering and determining nickel in aliquot portions of the filtrates by the dimethylglyoxime method, $0.203,1.13$, and 8.03 per cent were obtained in steels containing $0.288,1.21$, and 8.44 per cent, respectively. By making double precipitations with zinc oxide, as described in the determination of cobalt, and examining the final precipitates containing the iron, chromium, etc., no nickel was detected in the case of the steel containing 0.288 per cent of nickel, 0.02 per cent was found in the case of the steel containing 1.21 per cent, and 0.10 per cent in the case of the steel containing 8.44 per cent. These tests indicate that nickel is retained in the bulky precipitate even if two precipitations by zinc oxide are made. If the percentage of nickel is low, the retention is negligible. Single precipitations do not yield satisfactory separations. 


\section{TUNGSTEN}

If tungsten is oxidized to yellow tungstic acid before the addition of zinc oxide, none will be found in the filtrate. If it is not oxidized, a little will be found in the filtrate. This will contaminate cobalt if the cobalt is precipitated with $\alpha$-nitroso- $\beta$-naphthol. If an excess of zinc oxide is added to an acid solution containing no other elements, such as iron, that are precipitated, a large proportion of the tungsten remains in solution. The amount remaining in solution varies, because more is precipitated if the time of digestion is increased.

\section{VANADIUM}

In a solution containing no other elements that are precipitated, quadrivalent vanadium is completely precipitated, whereas quinquevalent vanadium divides, at least one-half passing in to the filtrate. Both quadrivalent and quinquevalent vanadium are completely precipitated if a tenfold excess of ferric iron is present. In the absence of ferric iron it is difficult to obtain a clear filtrate in the case of quadrivalent vanadium. Tests to ascertain the behavior of quinquevalent vanadium were made by adding ferrovanadium to ingot iron in such quantity that the mixtures contained $1 \mathrm{~g}$ of iron and 0,1 $\mathrm{g}$ of vanadium. These mixtures were dissolved, the iron and vanadium were oxidized, and the solutions treated with an excess of zinc oxide and filtered. Precipitations were made at $20^{\circ}$ and at $90^{\circ} \mathrm{C}$. The filtrates were acidified with sulphuric acid and treated with hydrogen peroxide. Less than $0.1 \mathrm{mg}$ of vanadium was found in any case. Similar tests of ferrovanadium alone (53 per cent of $\mathrm{Fe}$ and 31 per cent of $\mathrm{V}$ ) showed $0.1 \mathrm{mg}$ of vanadium in the filtrates obtained by precipitating at $20^{\circ}$ to $25^{\circ} \mathrm{C}$. and $0.2 \mathrm{mg}$ at $90^{\circ}$ to $100^{\circ} \mathrm{C}$.

\section{CHROMIUM}

Sexivalent chromium is not precipitated by zinc oxide; trivalent chromium is completely precipitated either in the presence or absence of iron.

\section{COPPER AND MOLYBDENUM}

Copper is almost completely precipitated in the absence of iron, but only about one-half of the molybdenum is precipitated under similar conditions. Copper to make 0.5 per cent was added to solutions of $1-g$ samples of ingot iron and of chrome-tungsten-vanadium steel, and double precipitations by zinc oxide were made. In six such tests the combined filtrates of each test showed from 0.2 to $0.5 \mathrm{mg}$ of copper. Similar tests, but using 0.5 per cent of molybdenum instead of copper, showed that from 1 to $2 \mathrm{mg}$ of molybdenum passed into the filtrate. Molybdenum and copper are precipitated by $\alpha$-nitroso- $\beta$-naphthol, but during the ignition of cobalt to oxide at temperatures between $750^{\circ}$ and $900^{\circ} \mathrm{C}$. the former is partially volatilized. Consequently contamination by molybdenum under these conditions seldom exceeds $1 \mathrm{mg}$.

The retention of cobalt in the precipitate formed by zinc oxide is slightly greater if the material contains as much as 0.5 per cent of copper or molybdenum. The average of six determinations of cobalt in such precipitates showed this retention to be $0.2 \mathrm{mg}$ greater 
than was the case when copper and molybdenum were absent. Tests have shown that if the material contains less than 0.15 per cent of copper or molybdenum, it is safe to ignore the retention of cobalt in the precipitate formed by zinc oxide, and also the contamination of the cobalt by copper and molybdenum. The two errors tend to cancel each other.

\section{URANIUM}

Sexivalent uranium is completely precipitated in the presence of a tenfold excess of ferric iron. In the absence of ferric iron $0.5 \mathrm{mg}$ and $0.6 \mathrm{mg}$ of uranium oxide, $\mathrm{U}_{3} \mathrm{O}_{8}$, were found in the filtrates in two tests, involving 10 and $20 \mathrm{mg}$ of uranium respectively. Quadrivalent uranium is completely precipitated in the absence of iron.

\section{ZIRCONIUM AND TITANIUM}

Zirconium and quadrivalent titanium are completely precipitated. Peroxidized titanium passes into the filtrate.

\section{SILICON}

Sodium silicate, equivalent to $0.02 \mathrm{~g}$ of silica, was added to $1 \mathrm{~g}$ of ingot iron, after which the iron was dissolved and oxidized. After making a precipitation with zinc oxide in the usual manner and filtering, the filtrate was tested for silica by dehydration with sulphuric acid. One milligram of silica was found.

\section{ALUMINUM}

Aluminum chloride, equivalent to $0.02 \mathrm{~g}$ of aluminum, was added to $1 \mathrm{~g}$ of ingot iron, after which the iron was dissolved and oxidized. A precipitation by zinc oxide was made in the usual manner, and the solution was filtered. No aluminum was found in the filtrate.

\section{PHOSPHORUS, ARSENIC, ANTIMONY, TIN (LEAD)}

Phosphorus (as orthophosphate) and tri and quinquevalent arsenic are quantitatively precipitated in the presence of a ten to twenty fold excess of ferric iron.

Trivalent antimony is almost completely precipitated in the presence of a ten to twenty fold excess of ferric iron. In tests involving 5 $\mathrm{mg}$ of antimony an average of only $0.3 \mathrm{mg}$ was found in the filtrates. Quinquevalent antimony is not completely precipitated in the presence or absence of ferric iron.

Bivalent tin is not completely precipitated. Quadrivalent tin is completely precipitated in the presence or absence of ferric iron. Filtration is difficult if much tin is involved.

Lead divides, but by far the greater part remains in the precipitate.

Antimony, tin, and lead are precipitated by $a$-nitroso- $\beta$-naphthol and must be taken into consideration if this reagent is to be used.

\section{CONCLUSIONS}

If a precipitation by zinc oxide is made in a solution of a steel obtained by dissolving the steel in hydrochloric or sulphuric acid and oxidizing with nitric acid, the precipitate will contain all of the 79688-31-9 
iron, tungsten, vanadium, chromium, uranium, zirconium, titanium, aluminum, phosphorus, arsenic, tin, and nearly all of the copper, molybdenum, and silicon. Ferrous iron, tungsten if not previously oxidized, and small quantities of silicon, copper, molybdenum, antimony, and lead may be expected in the filtrate if these were present in appreciable amounts.

Small amounts of sodium carbonate in the zinc oxide used in separating cobalt and manganese from iron, chromium, etc., are not objectionable if only a slight excess of reagent is added.

Separations of iron and certain other constituents of steel from cobalt and manganese by precipitating with zinc oxide are satisfactory if double precipitations are made. Results for cobalt tend to be low if only a single precipitation is made. Neither single nor double precipitations are entirely satisfactory for the separation of large amounts of nickel. The temperature at which precipitations by zinc oxide are made has very little influence on the results.

\section{ACKNOWLEDGMENT}

Acknowledgment is made to Dr. G. E. F. Lundell, under whose direction this investigation was made.

Washington, September 16, 1931. 